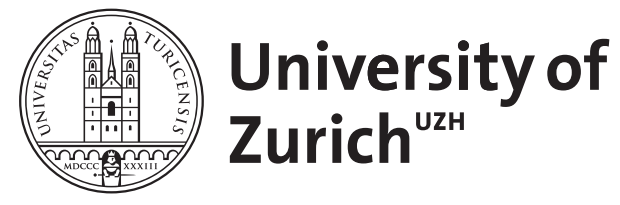

Zurich Open Repository and Archive

University of Zurich

University Library

Strickhofstrasse 39

CH-8057 Zurich

www.zora.uzh.ch

Year: 2000

\title{
A fresh look at grammatical relations in Indo-Aryan
}

Bickel, Balthasar

DOI: https://doi.org/10.1016/S0024-3841(99)00048-0

Posted at the Zurich Open Repository and Archive, University of Zurich

ZORA URL: https://doi.org/10.5167/uzh-76620

Journal Article

Originally published at:

Bickel, Balthasar (2000). A fresh look at grammatical relations in Indo-Aryan. Lingua, 110:343-373.

DOI: https://doi.org/10.1016/S0024-3841(99)00048-0 


\title{
A fresh look at grammatical relations in Indo-Aryan ${ }^{4}$
}

\author{
Balthasar Bickel ${ }^{a, *}$, Yogendra P. Yādava \\ a Department of Slavic Languages, University of California at Berkeley, \\ 6303 Dwinelle Hall, Berkeley, CA 94720-2979, USA and University of Zürich, Switzerland

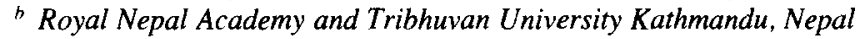

Received 26 May 1999; revised version 2 October 1999

\begin{abstract}
Verb agreement in Hindi has recently been shown to be sensitive to both argument structure and morphological case features (Mohanan, 1994): the verb agrees with the 'highest nominative' argument, i.e., with a nominative $S$ - or A-argument, or if there is no nominative $A$, with a nominative $\mathrm{O}$-argument (where $\mathrm{S}=$ 'single argument of intransitives', $\mathrm{A}=$ 'transitive actor', $\mathrm{O}=$ 'transitive object'). In this article we propose that such a combination of morphological and syntactico-semantic notions is a general characteristic of the over-all syntax of many if not all Indo-Aryan languages. On the basis of constructions which are demonstrably sensitive to grammatical relations, viz. verb agreement, gapping in nonfinite clauses, control constructions and matrix-coding ('raising'), we argue that these relations are defined as 'nominative or ergative S/A' in Maithili and Nepali. Hindi shows a split between some constructions being sensitive to the same grammatical relation and others to a notion of 'non-genitive S/A' (gapping in converb clauses) and to 'highest nominative' (agreement). Other constructions, viz. conjunction reduction, converbial reference control, and reflexivization, prove not to be sensitive to grammatical relations, in contradiction to frequent assumptions made in the literature on Indo-Aryan syntax. (c) 2000 Elsevier Science B.V. All rights reserved.
\end{abstract}

thesearch on this paper was supported by Grant No. Bi 591/1-2 (1995-1998) from the Deutsche Forschungsgemeinschaft and Grant No. $8210-053455$ (1998-2001) from the Swiss National Science Foundation. We would like to thank Prof. Surya Nāth Gope, Prof. Bālkrș̣na Pokharel, Dr. Bratrāj Ācāryā, Dr. Devīprasād Gautam, Karnāākhar Khativadāa, Rāmrāj Lohan̄i, Balrām Prasāī and Bhimnārāyan Regmī for sharing their native speaker intuitions with us and for their invaluable help and suggestions. We are also highly indebted to the participants of the 4th Himalayan Languages Symposium, Pune. 7-9 December 1998, for helpful discussion of an oral presentation of this paper and to Hindi speakers at the symposium who provided us with additional grammaticality judgements on the data reported in section 5. Many thanks also go to the editor of Lingua for a helpful query on an earlier version. All remaining mistakes and misconceptions are of course our own responsibility.

* Corresponding author. Phone: +1 510642 2979; Fax: +1 510642 6220; E-mail:

bickel@socrates.berkeley.edu; E-mail second author: yadava@yp.wlink.comp.np 
Keywords: Grammatical relations; Dative subject constructions; Indo-Aryan; Hindi; Nepali; Maithili

\section{Introduction}

Languages with ergative case-marking are well-known to often display accusative-style syntax (Anderson, 1976; Dixon, 1979, 1994; Foley and Van Valin, 1984; Van Valin and LaPolla, 1997; Lazard, 1994, etc.). Grammatical relations (GRs), as manifest in constructions like control or matrix-coding ('raising'), typically revolve around a notion of 'pivot' that is completely dissociated from the casemarking system of the language. In Bickel (1997; in press), the 'hidden' nature of such pivots is put into contrast with the overt case-marking of GRs in European languages such as German or Russian, where the nominative case desinence is a fairly reliable guide to the subject GR. Modern Indo-Aryan languages provide interesting cases in-between. Elaborating on earlier suggestions by Kachru et al. (1976), Mohanan (1994) has shown that agreement in Hindi operates on a combined morphological and syntactico-semantic notion of 'highest nominative argument', where 'highest' is defined on the Subject >> Object >> Adjunct hierarchy, and, by mediation of a linking theory (of the kind proposed by Bresnan and Kanerva, 1989, or with similar results, by Foley and Van Valin, 1984), ultimately on an argument role hierarchy ranging from most to least agentive arguments. This is illustrated by the following examples (Mohanan, 1994: 103-104): ${ }^{1}$

(1) a. Ravī bālak-ko uṭhāe-e-gā.

R.(M):NOM boy-DAT lift-3s-FUTsM

'Ravi will lift up the boy.'

\footnotetext{
All languages under consideration show 'differential object-marking' (Bossong, 1985), marking definite and other high-empathy objects of transitive verbs with the same case suffix that is used for the beneficiary argument of ditransitive verbs. We use the term 'dative' for this case. Case-markers in IndoAryan languages show properties of both enclitic postpositions and suffixes. We chose to represent them as suffixes. Consistent with this, we also represent aspectual modifier verbs ('vector verbs', 'explicators', 'postverbs', 'aspectualizers', 'aspectual verbs') as suffixes. Nothing crucial for our argument depends on these choices (except if Hindi agreement is analyzed as depending on a distinction between NP and PP - a proposal made by Gair and Wali, 1989, but shown by Mohanan, 1994: 105f., to result in problematic complications; also see Bickel, 1999, for discussion).

In interlinear glosses, we use the following abbreviations: ABL 'ablative', AUX 'auxiliary', CAUS 'causative', COMP 'complementizer', CONV 'converb (conjunct participle)', DAT 'dative', DEM 'demonstrative', ERG 'ergative', F 'feminine', FUT 'future', GEN 'genitive', h 'honorific', ICONV 'imperfective converb', IMP 'imperative', INF 'infinitive', INVOL 'involuntive', IP 'imperfective participle', IPFV 'imperfective', $M$ 'masculine', $N$ 'nominative (agreement feature)', NEG 'negative', NN 'non-nominative (agreement feature)', NOM 'nominative (case)', NPT 'non-past', OBL 'oblique (case)', p 'plural', P '(aspectually neutral/unmarked) participle', PASS 'passive', PRES 'present', PT 'past', REM 'remote', $s$ 'singular', TEL 'telic (Aktionsart)'.
} 

b. Ravī-ne roțī khā-yī.
R.(M)-ERG bread(sF):NOM eat-PTsF
'Ravi ate bread.'
c. Ravī roṭī khā-e-gā.
R.(M):NOM bread(sF):NOM eat-3s-FUTsM
'Ravi will eat bread.'

If there is only one nominative NP argument, the verb agrees with it regardless of whether it is subject (a) or object (b). If there are two nominative NP arguments, agreement is with the one higher on the role hierarchy, i.e., with the subject (c). The two conditions show that the Hindi agreement rule is sensitive to both case and argument role.

In this paper we argue that such a combination of morphological and syntactico-semantic notions is not limited to agreement nor to Hindi, but is a general characteristic of the over-all syntax of many if not all modern Indo-Aryan languages. We chose as case studies three languages with maximally distinct case and agreement typology, viz. Hindi, Nepali and Maithili. Hindi and Nepali, but not Maithili, have ergative case-marking, while Hindi and Maithili, but not Nepali, restrict syntactic agreement to nominative arguments. Maithili has in addition a secondary and a tertiary set of agreement markers that register oblique NPs, PPs and conversationally implicated discourse referents (Yadava, 1996; Bickel et al., 1999).

Our arguments are based on three sets of GR-sensitive constructions: apart from verb agreement, we explore gapping in nonfinite (infinitival, participial and converbial) clauses and argument sharing in control and matrix-coding ('raising') constructions. For each construction, we first demonstrate that it is at all sensitive to a GR before determining the exact nature of this GR. This methodological precaution is highly needed because much discussion of Indo-Aryan GRs rests on prima facie evidence which uncritically assumes that constructions like reflexives, converb chains, and conjunction reduction are GR-sensitive in all languages. Closer scrutiny reveals this to be an unwarranted assumption.

We proceed as follows: in section 2 we define some analytical terms and discuss the basic assumptions we make about the mapping from argument semantics to syntax. Section 3 is devoted to issues of agreement, focusing in particular on the complex patterns found in Maithili. In section 4 we discuss GR-sensitive constructions, showing that in each of them, the definition of GRs must include reference to one or two case features, partly in the same way through all three languages, and partly in differing ways. Section 5 takes issue with the frequent claims in the literature that experiencer datives have subject properties in Indo-Aryan languages. We demonstrate that such claims are based on untenable analyses of the constructions which are used to test for subjecthood. Section 6 summarizes our findings and draws some conclusions of theoretical interest. 


\section{Grammatical relations, pivots and argument roles}

In this paper, we use the term 'pivot' as a morphology-free notion defined as the partial neutralization of argument roles in a certain construction (cf. Dixon, 1979; Foley and Van Valin, 1984; Van Valin and LaPolla, 1997; Palmer, 1994). Using what has become the standard abbreviations $-\mathrm{S}$ for the 'single argument of intransitives and passives', $\mathrm{A}$ for the 'most agentive argument of transitives' and $\mathrm{O}$ for the 'most patientive argument of transitives' - we define ' $S / A$ ' as an accusative-style pivot and ' $\mathrm{S} / \mathrm{O}$ ' as an ergative-style pivot. We distinguish 'pivot' from a more general notion of 'grammatical relation' (GR) which can be defined by any argumentbased constraint on a construction and may involve pivots as well as morphological or phrase-structural features.

We assume that $\mathrm{S}, \mathrm{A}$ and $\mathrm{O}$ are strictly determined by the semantic argument structure of the predicate. Predicates with only one argument license an S-argument, irrespective of its case. Thus, we assume that both of the following Maithili examples contain an S-argument:

(2) a. o

$$
\text { hãs-1-aith. }
$$

3hREM:NOM laugh-PT-3hN

'He h.rem laughed.'

b. hunkā hãs-ā-ge-l-ainh.

3hREM:DAT laugh-INVOL-TEL-PT-3hNN

'He $\mathrm{e}^{\text {h.rem }}$ burst into laughing.'

Example (b) is as intransitive as (a), but it is marked by the 'involuntive' morpheme (cf. Gair, 1971; Bashir, 1990), which signals that the highest argument of the host predicate is not so much a willful instigator of an action but rather its experiencer. As a concomitant of involuntive marking, the corresponding NP receives dative instead of nominative case-marking. This, however, does not change the status of this NP as S, i.e., as the single argument of an intransitive clause. ${ }^{2}$ The predicate does not become impersonal or 'a-transitive' like, say, a weather expression (cf. Van Valin and LaPolla, 1997: 150), and therefore still obligatorily triggers verb agreement (although of a different type than with nominative S-arguments - see section 3 below).

Determining the A- and O-arguments of transitive verbs is in most cases straightforward. In the languages under consideration, the choice of $A$ and $O$ depends on the universal hierarchy of thematic roles reproduced in (3) (cf., among many others, Foley and Van Valin, 1984; Givón, 1984; Bresnan and Kanerva, 1989 for similar hierarchies in different theoretical frameworks):

2 For reasons against assuming a 'split' $S$ in Maithili, see below. 
(3) Thematic hierarchy

$\begin{array}{lllll}\text { A } \longleftrightarrow \text { Agent } & \text { Effector } & \text { Goal } & \text { Locative Theme Patient } \\ & \text { Perceiver } & \text { Experiencer } & \text { Stimulus } \\ \text { Possessor } & \text { Recipient } & \text { Possessed } \\ \text { etc. } & \text { etc. } & \text { etc. } & \end{array}$

Most important for our current purposes is that experiencers range higher than stimuli. Therefore, from the point of view of argument structure, both the experiencers $o$ ' $\mathrm{s} / \mathrm{he}$ ' in (4a) and hunka 'him/her' in (4b) are higher on the hierarchy than the sources of the experience; hence, the experiencers are A-arguments whereas the stimuli are $\mathrm{O}$-arguments in both examples:
(4) a. o okrā cāh-ait ch-aith.
3hREM:NOM 3nhREM:DAT like-IP AUX-3hN
b. hunkā u man par-ait ch-ainh.
3hREM:DAT 3nhREM:NOM liking occur-IP AUX-3hNN
'S/he h.rem likes him/her ${ }^{\text {nh.rem.' }}$

Thus, as with intransitive clauses, the case frame is irrelevant for determining argument roles. While we assume that argument role assignment is strictly predicted by the semantic structure of the predicate, it does not follow that $\mathrm{S}, \mathrm{A}$ and $\mathrm{O}$ must be mapped into GRs, and in the following sections we will indeed demonstrate that dative-marked S/A-arguments are not included in the definition of language-specific $\mathrm{GRs}^{3}$ - in spite of the fact that the verb agrees with such arguments as in the preceding examples. It is characteristic of Maithili that the verb obligatorily agrees with dative-marked S- (2b) and A-arguments (4b). However, in the next section we will see that this type of agreement does not involve a GR.

\section{Agreement and the multiple agreement challenge from Maithili}

In a recent paper, Yadava (1997) proposed that Mohanan's (1994) analysis of Hindi, which was briefly illustrated in the introduction, essentially carries over to Nepali and Maithili in that the agreement rules of all three languages make reference to case as much as to pivots. The languages differ, however, as to which particular cases are relevant.

Where there are two nominative NPs in a Nepali clause, agreement is with the higher argument, just as in Hindi. Unlike in Hindi, however, there is no agreement with nominative objects. Instead, the verb agrees with the ergative A-argument:

\footnotetext{
3 Like case-marking, other predicate-specific properties of arguments may block projection of experiencers into a specific GR as well. In English, for example, predicates like please or surprise assign the experiencer to a postverbal position and this phrase-structural property blocks the argument from functioning as the S/A-pivot in constructions such as raising or coordination. This is further discussed in Bickel (1999).
} 
(5) a. ma yas pasal-mā patrikā kin-ch-u.

1sNOM DEM:OBL store-LOC newspaper:NOM buy-NPT-1s

'I buy the newspaper in this store.'

b. maile yas pasal-mā patrikā kin-ẽ. (*kin-yo)

1sERG DEM:OBL store-LOC newspaper:NOM buy-PT1s buy-PT3sM 'I bought the newspaper in this store.'

Thus, the agreement rule of Nepali reads:

(6) Nepali agreement rule:

The verb agrees with the nominative or ergative S/A-argument.

Arguments in other cases never trigger agreement, regardless of whether they are in A-role (7a) or O-role (7b):

(7)
a. malāì tim̄̄ man par-ch-au.
1sDAT 2mhNOM liking occur-NPT-2mh occur-NPT-1s
'I like you.'
b. hijo usle timīlāì bajār-mā dekh-yo. (*dekh-yau) yesterday 3sERG 2mhDAT market-LOC see-PT3sM see-PT2mh 'Yesterday he saw you in the market.'

This also holds for the (derived) S-argument of passive sentences which are optionally encoded by datives (8a). If $S$ is in the nominative, by contrast, it triggers agreement, although an impersonal construction is possible as well (8b).
(8) a. malāî thag-T̃-yo
1sDAT cheat-PASS-PT3sM cheat-PASS-PT1s
'I got cheated.'
b. ma thag-ĩ-ẽ
$1 \mathrm{sNOM}$ cheat-PASS-PT1s cheat-PASS-PT3sM
'I was cheated.'

[N]

In Maithili, the rules of agreement are more complex, since, as we saw in examples (2b) and (4b) in the preceding section, even dative S/A-arguments trigger agreement. However, as a closer look at the examples and the overview in Table 1 makes evident, the agreement markers for oblique NPs are with few exceptions systematically different from the nominative agreement markers (Bickel et al., 1999). Maithili verb inflection is directly sensitive to the difference in how arguments are case-marked. A dative S-argument triggers 'non-nominative' agreement, while a nominative $\mathrm{S}$-argument controls 'nominative' agreement:

$\begin{array}{lll}\text { (9) a. hunkā } & \text { dar lag-l-ainh. } \\ \text { 3hREM:DAT fear feel-PT-3hNN } & \text { (*lag-l-aith) } \\ \text { feel-PT-3hN }\end{array}$ 

b. o
dar-l-aith.
(*dar-l-ainh)
3hREM:NOM be.afraid-PT-3hN be.afraid-PT-3hNN
'He $\mathrm{H}^{\text {h.rem }}$ was afraid.'

Table 1

Nominative and non-nominative single agreement in Maithili (Bickel et al., 1999)

\begin{tabular}{|c|c|c|c|}
\hline Person & Tense & Nominative & Non-nominative \\
\hline \multirow[t]{3}{*}{$1 / 2 \mathrm{~h}$} & present & $-i$ & ai- \\
\hline & past & $-a u ̃(h) \sim-i$ & $\varnothing$ \\
\hline & future & $-b$ & $-t$ \\
\hline \multicolumn{2}{|l|}{$2 \mathrm{nh}$} & $-\mathfrak{x}$ & $-a u(k)$ \\
\hline \multicolumn{2}{|l|}{$2 \mathrm{mh}$} & \multicolumn{2}{|c|}{$-a(h)$} \\
\hline \multirow[t]{3}{*}{$3 \mathrm{nh}$} & present & \multicolumn{2}{|c|}{ ai- } \\
\hline & past & $-\mathrm{a}(\mathrm{k}) \sim \emptyset$ & $\varnothing$ \\
\hline & future & \multicolumn{2}{|c|}{$-t$} \\
\hline \multirow[t]{2}{*}{$3 \mathrm{~h}$} & present/past & -aith & -ain(h) \\
\hline & future & $-t-\bar{a}(h)$ & -t-ain(h) \\
\hline \multirow[t]{2}{*}{$3 \mathrm{hh}$} & present/past & -ath-inh & -ain(h) \\
\hline & future & -t-ah-inh & -t-ain(h) \\
\hline
\end{tabular}

While occasionally, the difference between non-nominative and nominative agreement correlates with a difference in control (cf. the examples in 2 above), this is not always the case. Nominative agreement covers agents (10a) as much as patients $(10 \mathrm{~b})$ :

(10)
kitāb
nahi paḍh-l-aith.
3hREM:NOM book:NOM not read-PT-3hN 'He ${ }^{\text {h.rem }}$ didn't read the book.'
b. 0
khas-l-aith.
3hREM:NOM fall-PT-3hN
'He h.rem fell.'

Likewise, non-nominative agreement can index the most patientive (11a) as much as the most agentive (11b) arguments of bivalent predicates:

(11) a. u

$$
\text { hunkā māra-l-k-ainh. }
$$

\section{3nhREM:NOM 3hREM:DAT beat-PT-3N-3hNN}

'S/hen ${ }^{\text {nh.rem }}$ beat him/her.rem.'

b. hunkā-sã kitāb nahi paḍha-l ge-l-ainh.

3hOBL-ABL book:NOM not read-P AUX:PASS-PT-3hNN

'The book was not read by him/her.rem.'

Thus, the distinction does not rely on a 'split-S' or 'fluid-S' system as described by Dixon (1994) nor does it reduce to a difference in what is called 'initial GR' in Relational Grammar. The only systematic correlate of the inflectional split is the case- 
frame that is used with each verb. ${ }^{4}$ Frames with non-nominative agreement often associate with experiencer constructions, but this is, as is evidenced by (11b), by no means necessarily so.

Non-nominative agreement is obligatory with arguments, but the same marking is optionally also used to index other participants, whether they are overt in the clause or taken from the wider context. In these cases, non-nominative marking fulfills similar functions as a dativus (in)commodi (12a) or an external possessor (12b):

(12) a. ham cail-je-b-ah.

INOM move-TEL-FUT[1N]-2mhNN

'I will go away (if you ${ }^{\text {mh }}$ don't want me to stay).'

b. ham okrā mār-l-i-ah.

INOM 3nhREM:DAT beat-PT-1N-2mhNN

'I beat him ${ }^{\text {nh.rem }}$ (who is related to you ${ }^{\mathrm{mh}}$, etc.).'

As argued by Bickel et al. (1999), non-nominative agreement in Maithili is more an index of social status rather than of a specific GR. By stark contrast, nominative agreement strictly follows the pattern defined in (6) for Nepali. However, since there is no ergative case in Maithili, the agreement rule can be reduced to the following:

\section{(13) Maithili syntactic agreement rule:}

The verb agrees with the nominative S/A-argument.

A dative S-argument can therefore never trigger nominative agreement, and this is exactly what we found in example (9).

\section{Complex constructions constrained by grammatical relations}

In the preceding section we saw that in all the three languages, verb agreement at least in strictly syntactic systems - refers to a GR that is simultaneously defined by argument roles ('S/A', 'highest argument') and case features ('nominative', 'nominative or ergative'). In this section, we discuss a series of complex constructions which are constrained by a specific type of GR. We will see that the definition of these GRs systematically excludes arguments in the dative, even if they bear the $\mathrm{S}$ - or A-argument role.

\footnotetext{
4 Alternatively, one could say that the agreement choice correlates with a lexical diacritic such as 'M[acrorole]-transitivity' as proposed in Role and Reference Grammar (Van Valin and LaPolla, 1997): the verbs in (2b) and (9a) would be marked as 'M-atransitive' and nominative agreement would be limited to verbs with at least one Macrorole. Whether case frames are taken in this manner to follow from M-transitivity, whether they are analyzed as lexical idiosyncrasies, or whether they are derived from independent constructional principles (Goldberg, 1995), is a theoretical question beyond the scope of this paper (but see Bickel, 1999).
} 


\subsection{Nonfinite clauses}

Infinitival and participial clauses in Hindi and Maithili behave like their counterparts in Western Indo-European languages: they proscribe NPs with a certain case feature. Whereas Maithili exactly parallels Germanic or Slavic in banning the nominative, Hindi also bans the ergative from appearing on S/A-arguments in such clauses:

(14) Maithili and Hindi constraint on infinitives and participles:

Infinitival and participial clauses must not contain an overt nominative or ergative S/A-argument. If the S/A-argument is to be overt, its case must be demoted to the genitive or dative.

Hindi resorts to genitives in both complement and attributive clauses, although datives also seem to be possible in at least some varieties. The following examples illustrate a subject complement clause:
a. *[Rām-ne/Rām ais̄i kitāb R.-ERG/R.:NOM such book:NOM read-INF right not is
b. [Rām-kā/Rām-ko aisī kitāb paḍh-na] țhīk nahĩ hai. R.-GENsM/R.-DAT such book:NOM read-INF right not is 'It is not good for Ram to read such a book.'

The same pattern holds in attributes, but the genitive case marker, like all attributemarking morphemes in Hindi, inherits the gender and number features of the head noun:

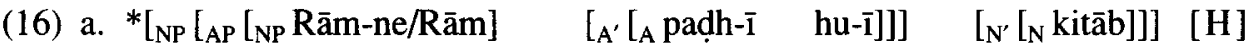
R.-ERG/R.:NOM read-PsF AUX-PsF book(sF)

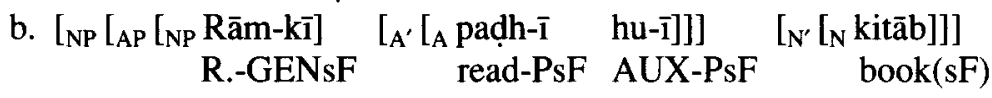
'the book read by Ram'

Maithili also uses genitives in attribute clauses, but resorts to datives in complement clauses:

(17) a. *[Rām ehan kitāb paḍh-ab] thīk nahi ai-ch. R.:NOM such book:NOM read-INF right not 3-be

b. [Rām-kẽ ehan kitāb padh-ab] thīk nahi ai-ch. R.-DAT such book:NOM read-INF right not 3-be 'It is not good for Ram to read such a book.'

In neither Hindi nor Maithili are dative S-arguments affected by the demotion rule in (14) (cf. Hook, 1990). Indeed, replacing datives by genitives is ungrammatical: 


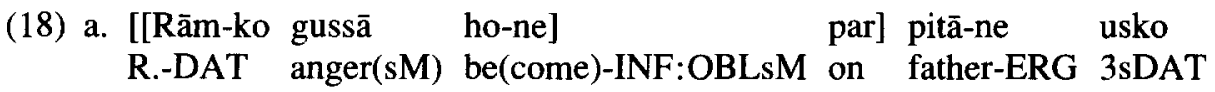
pit-ā. beat-PTsM

b. *[[Räm-ke R.-GEN:OBLsM anger(sM) be(come)-INF:OBLsM on father-ERG usko piț-ā. 3DAT beat-PTsM 'Father beat Ram when he became angry.'

In Maithili, too, there is a clear contrast between nominative S-arguments which are demoted to genitive as in (19a) and dative S-arguments which retain their case (19b):
a. [[Rām-ak/*Rām kæ-l ge-l] kāj] R.-GEN R.:NOM do-P AUX-P work 'the work done by Ram'
b. [[Rām-kẽ nik lāg-al] cij] R.-DAT good feel-PT thing 'the thing that Ram felt good about'

Hindi extends the ban on overt S/A-arguments with specific case-markers onto the sequential converb (also known as 'conjunctive participle', 'absolutive' or pürvakälik kriya ' 'prior tense verb'). S/A-arguments in the nominative, the ergative and the dative are impossible - except for a few lexically specified expressions such as äth baj-kar 'having struck eight, at eight o'clock' (cf. Guru, 2026: §627; Schumacher, 1977: 76-94): ${ }^{5}$

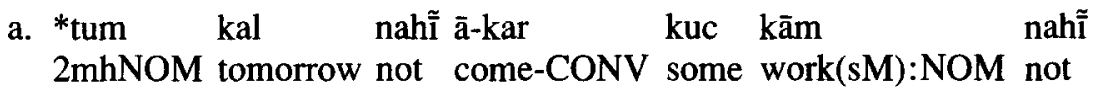 ho-gā. be:3s-FUTsM
'If you don't come tomorrow, there won't be any work.'
b. *pitā-jī-ne ciṭhī likh-kar calā-ga-yā. father-h-ERG letter:NOM write-CONV move-TEL-PTsM 'After writing a letter, father went away.'
c. *Harī-ko buqhār ā-kar maĩ cintit ho-ga-yā. H.-DAT fever come-CONV 1sNOM worried be(come)-TEL-PTsM 'When Hari got fever, I became worried.'

\footnotetext{
5 Other exceptions noted by Schumacher (1977) are not fully convincing since they all involve verbs of existence or emergence in either the converh or the main clause: in some cases, the nominative could as easily be analyzed as part of the (complex) converb predicate instead of as its subject and in other cases as the subject of an existential main clause predication. Some other examples seem to be anacoluthic, as Schumacher states himself (1977: 93).
} 
The same holds for the imperfective converb in -e:

(21) a. *tum phār-e yah gãțh nahĩ phate-e-gī.

$2 \mathrm{mhNOM}$ split-ICONV DEM $\log (\mathrm{sF})$ :NOM not split-3s-FUTsF

'Inspite of your splitting, this log won't split apart.'

b. *mujhe buqhār $\bar{a}-\mathrm{e}$ (hu-e) usne kām

1sDAT fever come-ICONV AUX-ICONV 3sERG work(sM):NOM ki-yā.

do-PTsM

'He did the work when I suffered from fever.'

However, if demoted to genitive, an S/A-argument can appear in a converb clause (cf. Guru, 2026; Schumacher, 1977; Subbarao, 1984):

(22)
a. tumhāre kal nahĩ ā-kar kuc kām nahĩ $[H]$ 2 mhGEN tomorrow not come-CONV some work(sM):NOM not ho-gā.
be:3s-FUTsM
'If you don't come tomorrow, there won't be much work.'
b. tumhāre phārr-e yah gẫth nahî̃ phat-e-gī.
2mhGEN split-ICONV DEM $\log (\mathrm{sF})$ :NOM not split-3s-FUTsF

'Inspite of your splitting, this log won't split apart.' (Schumacher, 1977: 202)

Thus, the constraint does not involve a general notion of S/A-pivot, but is again sensitive to a specific case feature:

(23) Hindi constraint on converbs:

Apart from a few lexically determined exceptions, an overt S/A-argument in Hindi converb clauses can only be in the genitive.

In Maithili, $\mathrm{S} / \mathrm{A}$-arguments are banned from converbs if they are in the nominative but not if they are in the dative:
a. *ham ghar āib-kē
pitā-jī
khuśī he-t-āh.
1NOM home come-CONV father-h:NOM happy be(come)-FUT-3hN
b. hamrā ghar āib-kẽ
pitā-jī
khuśī he-t-āh.
IDAT home come-CONV father-h:NOM happy be(come)-FUT-3hN
'When I come home, father will be happy.'

Thus, Maithili converb clauses are subject to the same constraint as infinitival and participial clauses (cf. 14). Crucially, the construction is again sensitive to both case features and argument roles.

Nepali is different from Hindi and Maithili in overtly allowing subjects without enforcing any case demotion rule (cf., among others, Verma, 1976). Both nomina- 
tive and ergative are fine in complement (25), attribute (26) and converb (27) clauses: ${ }^{6}$

(25) a. [Rām ghar jā-nu] thik hoina.

R.:NOM home go-INF right is.not

'It's not good for Rām to go home.'

b. [Rām-le yasto kitāb paḍh-nu] thik hoina.

R.-ERG such book:NOM read-INF right is.not

'It's not good for Rām to read books.'

(26) a. [[Rām ga-eko] bāṭo]

R.:NOM go-P way

'the way Rām went'

b. [[Rām-le gar-eko] kām]

R.-ERG do-P work

'the work done by Rām'

(27) a. timī bharai na-ā-ikana hāmro gaph-ai jã -daina. [N]

2sNOM evening NEG-come-CONV 1pGEN chat-EMPH go-NPT3sNEG

'Unless you come in the evening, our chat can't go on.' (Clark, 1989: 164)

b. timī-le bhan-era mātrai yo kām gar-yo.

2mh-ERG say-CONV only DEM work:NOM do-PT3sM

'He did this only because you told him so.'

Thus, considered by themselves, non-finite clauses in Nepali are not sensitive to any GR-notion at all. This is different when we look at non-finite clauses embedded in control constructions, to which we turn in the next section.

\subsection{Argument sharing in control constructions}

If used with infinitival or participial complements, some verbs impose obligatory control of one of the subordinate arguments. In all the three languages under consideration, this is the nominative or ergative S/A-argument, but never a dative NP even if it is in S/A-role:

(28) Constraint on argument sharing (Hindi, Maithili, Nepali):

The shared argument (i.e., the argument position that is obligatorily covert and coindexed with a higher-clause argument) in a control construction must be a nominative or ergative S/A-argument.

Shared arguments in control constructions correspond to what is sometimes referred to as 'PRO under obligatory control' but the notion chosen here, which we

\footnotetext{
6 Converbs without demotion rules or subject coreference constraints are attested in other Indo-Aryan languages as well, notably in Marathi (Pandharipande, 1990: 178). Rosen and Wali (1989: 14f.) provide counter-examples to Pandharipande's findings, which, however, are not conclusive because they involve agentive verbs in the matrix clause. From a general Indo-Aryan perspective, it seems to us pragmatically unlikely that one would get non-subject coreference in such cases (e.g., $C$ having $V$-ed, $A$ gives $B$ to $C$ ).
} 
adopt from Van Valin and LaPolla (1997), will allow simpler generalizations in later sections. Shared arguments are obligatorily, rather than optionally, gapped and coindexed (EQUI-deleted) and cannot therefore be replaced by overt lexical NPs even if these NPs have a different reference from any matrix-clause argument. This is important to notice because the Argument Sharing Constraint in (28) exclusively refers to cases like (29), where ' $\varnothing$ ' represents an argument that is shared, i.e., both coindexed and obligatorily covert:

(29) a. Rām-ne Harī-ko ${ }_{i}\left[\emptyset_{i, *_{j}}\right.$ usko $*_{i}$ piț-ne-ke

liye] $[\mathrm{H}]$

R.-ERG H.-DAT 3sDAT beat-INF:OBLsM-GEN:OBLsM for

kah-ā.

tell-PTsM

'Ram told Hari to beat him.'

b. *Rām-ne Harī-ko ${ }_{i}\left[\mathrm{vah} / \mathrm{uske} \quad \emptyset_{i}\right.$ pit-ne-ke

R.-ERG H.-DAT 3sNOM/3sGEN beat-INF:OBLsM-GEN:OBLsM

liye] kah-ā.

for tell-PTsM

'Ram told Hari to get beaten by him.'

As shown by the referential indices in (29a), the A-argument must be coreferential with Hariko and, as is evident from the ungrammaticality of (29b), it must not be overt. This is different from the non-controlled infinitival constructions we looked at in the preceding section, where S/A-arguments could appear in a demotion case (genitive or dative). Non-shared argument can of course also be gapped, resulting in ' $P R O$ under optional control'. If they are gapped, they have the properties of a $P R O$ element and can therefore be controlled (30a). Unlike shared elements, however, their reference can also be free or 'arbitrary' (30b):
a. $\left\lfloor P R O_{i}\right.$ khālī kar-ne-ke
liye]
empty make-INF:OBLsM-GEN:OBLsM for
nāvik-ne nāv-ko ${ }_{i} \quad \overline{a g e}$ baḍhā-yā.
boatsman-ERG boat-DAT forward move-PTsM
'The boatsman moved the boat [into the port] in order to unload it.'
b. dạktar-ne Rām-ko $\left[P R O_{a r b}\right.$ bhūk lag-ne-ke doctor-ERG R.-DAT appetite feel-INF:OBLsM-GEN:OBLsM
liye] davā d-i.
for medicine(sF):NOM give-PTsF
'The doctor gave Ram medicine for feeling appetite.'

Thus, two features distinguish shared arguments $(\phi)$ from other instances of $P R O$ : (i) the fact that they do not alternate with overt NPs and (ii) the fact that their reference is obligatorily controlled.

Shared arguments in Hindi can be S-arguments (31a) as much as A-arguments in either nominative (31b) or ergative (31c) case-function: 
(31) a. Rām Hari ${ }_{i}$ par [ $\emptyset_{i}$ nahĩ gir-ne-ke

liye] $[\mathrm{H}]$

R.:NOM H.:OBL on not fall-INF:OBLsM-GEN:OBLsM for

cillī̄-yā.

shout-PTsM

'Ram shouted at Hari not to fall.'

b. $\operatorname{vah}_{i}\left[\begin{array}{lll}\emptyset_{i} & \text { sāikal calā-nā }] & \text { cāh-tā }\end{array}\right.$

3sNOM NOM cycle(sF):NOM manipulate-INFsM want-IPsM

hai.

AUX:3sM

'He wants to ride a bike.'

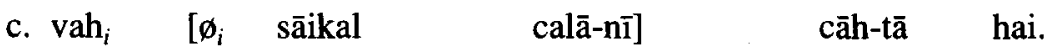

3sNOM ERG cycle(sF):NOM manipulate-INFsF want-IPsM AUX:3sM

'He wants to ride a bike.'

The difference between shared nominatives (31b) and shared ergatives (31c) can be recovered through the gender agreement found on the infinitive (Subbarao, personal communication): if the shared argument is associated with the nominative case, the infinitive agrees with it, otherwise the infinitive agrees with the nominative object. This follows in a straightforward manner from the regular Hindi agreement pattern. ${ }^{7}$

By contrast to S/A-arguments in nominative or ergative cases, dative $\mathrm{S}$-arguments as in (32a) cannot be shared (32b) (cf. Klaiman, 1979; Davison, 1985a; Hook, 1990). To be sure, they can be gapped as we saw in (30b) above, but they cannot be the obligatorily shared argument in control constructions. Only the nominative versions, where dar- 'fear' is used as an intransitive verb, are possible $(32 \mathrm{c}):^{8}$

(32) a. Harī-ko dar nahĩ hu-ā.

H.-DAT fear not be(come)-PTsM

[H]

'Hari was not afraid.'

b. *Rām-ne Harī-ko ${ }_{i}\left[\emptyset_{i}\right.$ dar nahĩ ho-ne-ke

R.-ERG H.-DAT fear not be(come)-INF:OBLsM-GEN:OBLsM

liye] kah-ā.

for tell-PTsM

'Ram told Hari not to be afraid.'

c. Rām-ne Harī-ko ${ }_{i} \emptyset_{i}$ nahî̀ dar-ne-ke liye]

R.-ERG H.-DAT not fear-INF:OBLsM-GEN:OBLsM for

\footnotetext{
7 Version (31c) is generally more 'marked' than (31b) and seems to focus the object, but the two constructions are not equally used in all dialects. See Hook (1979: 29f.) and Davison (1988) for some discussion.

8 We concur with Klaiman (1979) that Kachru et al.'s (1976) alleged counterexamples to this do not involve argument sharing ('EQUI') since they allow a generic (arbitrary) reading of the empty argument position (PRO), cf., e.g., Rāmne ${ }_{i}\left[P R O_{i l a r b}\right.$ bhükh lagnekī] bät batäi 'Ram told of being hungry'. On Klaiman's (1979) account, the ungrammaticality of ( $32 \mathrm{~h}$ ) results from a general constraint against deleting lexically specific experiencer NPs. Postulating such a constraint is in conflict, however, with examples like Ravìko Niña dikhī aur baḍi khusí huī 'Ravi saw Nina and was very happy.' (Mohanan, 1994: 149; also cf. Wallace, 1985a: 141 on Nepali).
} 
kah-ā.

tell-PTsM

'Rām told Hari not to be afraid.'

In this behavior, dative $\mathrm{S}$-arguments are like objects, which, too, can function as PRO (30a), but not as ' $\emptyset$ ' (29b).

The same pattern holds in Maithili and, as Verma (1990: 97) reports, also in Bhojpuri and Magahi. Object sharing is again ungrammatical (33a) and among S/A-arguments, only those associated with nominative case (33b), but not those associated with the dative (33c), can be shared:
(33) a. Rām Har̄̄-kẽ $\tilde{e}_{i}\left[\emptyset_{i,{ }_{j}}\right.$ okrāā ${ }_{*_{i}} \quad$ piṭ-bāk lel] kaha-l-ak. [M] R.:NOM H.-DAT 3nhREM:DAT beat-INF:OBL for tell-PT-3N 'Ram told Hari to beat him ${ }^{\text {nh.rem.' }}$
b. Rām Harī-kẽ $\tilde{e}_{i}\left[\emptyset_{i}\right.$ nahi ḍar-bāk lel] kaha-l-ak. R.:NOM H.-DAT not fear-INF:OBL for tell-PT-3N 'Ram told Hari not to be afraid.'
c. *Rām Harī-kẽ $\tilde{e}_{i}\left[\emptyset_{i}\right.$ ḍar nahi ho-bāk lel] kaha-l-ak.
R.:NOM H.-DAT fear not be(come)-INF:OBL for tell-PT-3N 'Ram told Hari not to be afraid.'

Nepali control constructions, too, follow the principle set out in (28): an S- (34a) or A-argument (34b) cannot appear overtly and must be controlled by the matrix clause. Objects, by contrast, do not allow argument sharing (34c) and neither do dative experiencers (34d) (cf. Wallace, 1985b):

(34) a. Rām-le Harī-lāì [ø (*u) na-ḍarāu-na] bhan-yo.

[N]

R.-ERG H.-DAT 3sNOM NEG-fear-INF tell-PT3sM

'Ram told Hari not to get afraid.'

b. Harī-lāi [ø (*us(-le)) Kạtḥmāṇụū-mā paḍh-na] pațhā-yo.

H.-DAT 3s-ERG K.-LOC study-INF send-PT3sM

'He sent Hari to study in Kathmandu.'

c. *sardār-le cor-haru-lāīi ${ }_{i}$ [pulis-le $\emptyset_{i}$ na-dekh-na] bhan-yo.

chief-ERG thief-p-DAT police-ERG NEG-see-INF tell-PT3sM

"The chief told the thieves not to be seen by the police."

d. *Rām-le Harī-lāi [ $\varnothing$ ḍar na-lāg-na] bhan-yo.

R.-ERG H.-DAT fear NEG-feel-INF tell-PT3sM

'Ram told Hari not to be afraid.'

The examples from Hindi and Maithili above show that clauses marked by the purposive postpositions liye and lel, respectively, are subject to the Argument Sharing Constraint. This only holds, however, if the matrix verb is specified as a control

\footnotetext{
9 An acceptable version of this resorts to a quote construction: sardärle corharulät " [pulisle $\emptyset_{i}$ nadekhos hail" bhanera bhanyo "The chief told the thieves ${ }_{i}$ "Don't let the police see $\emptyset_{i}$ !".
} 
verb. In other contexts, a postposition-marked purpose clause can have an overt S/Aargument, although its case must be demoted following the pattern discussed in section 4.1:
a. [Rām-ko (*Rām) so-ne-ke liye]
R.-DAT R.:NOM sleep-INF:OBLsM-GEN:OBLsM for
maĩ yahã̃-se calā-ga-yā.
$1 \mathrm{sNOM}$ here-ABL move-TEL-PTsM
'I moved away from here in order for Ram to (be able to) sleep.'
b. [Rām-kẽ (*Rām) sut-b-āk lel]
R.-DAT R.:NOM sleep-INF:OBL-GEN for
ham yahĩ thāam-sã uṭ̂̄-ge-l-aũh.
1 NOM here place-ABL rise-TEL-PT-1N
'I got up from this place in order for Ram to (be able to) sleep.'

In Nepali, by contrast, all postposition-marked purpose clauses are subject to the Argument Sharing Constraint. Therefore, the sentence type of (35) does not directly translate, as shown in (36a). Deleting the embedded S-argument results in Argument Sharing and therefore requires coreference with the matrix clause controller (36b). The intended meaning can only be brought about by resorting to a permissive construction that changes Ram's role into object (36c):
a. *[Rām(-lāi) sut-na-kā lāgi] ma chito gai-hāl-ẽ. [N] R.-DAT sleep-INF-GEN:OBL for 1sNOM quickly go-TEL-PT1s 'I quickly left so that Ram could sleep.'
b. $\left[\Phi_{i, * j}\right.$ sut-na-kā
lāgi] $\mathrm{ma}_{i}$
chițo gai-hāl-ẽ.
sleep-INF-GEN:OBL for 1sNOM quickly go-TEL-PT1s
'I quickly went to sleep.'
c. $\left[\emptyset_{i}\right.$ Rām-lāī sut-na di-na-kā lāgi $]$ ma $_{i}$ chito
R.-DAT sleep-INF give-INF-GEN:OBL for 1sNOM quickly gai-hāl-ẽ.
go-TEL-PT1s
'I quickly left in order to let Ram sleep.'

The Argument Sharing Constraint on this construction follows again the formulation in (28), whence dative NPs (37a) cannot be shared (37b) even if they are S-arguments. To render the intended meaning (37b), one has to resort to a reported thought construction $(37 \mathrm{c})$ :

(37) a. uslāĩ nidrā lāg-ena.

3sDAT sleep feel-PT3sM:NEG

'He didn't get sleepy.'

b. ${ }^{*}\left[\varnothing_{i}\right.$ nidrā na-lāg-na-kā lāgi $]$ usle ${ }_{i}$ redio sleep NEG-feel-INF-GEN:OBL for 3sERG radio:NOM 
kholi-rākh-yo.

open-keep-PT3sM

'He kept the radio on in order not to get sleepy.'

c. pro $_{i}$ nidrā na-lāg-os bhanera usle redio $_{i}$

sleep NEG-feel-3sIMP QUOTE 3sERG radio:NOM

kholi-rākh-yo.

open-keep-PT3sM

'He kept the radio on in order not to get sleepy.'

(Literally 'Thinking "[I] shouldn't get sleepy", he kept the radio on.')

Exactly the same distribution holds for object NPs:
a. *[Rām-le
$\emptyset_{i}$ na-karāu-na-kā
lāgi] $\mathrm{ma}_{i}$
R.-ERG ga-ẽ.
gharai
home:OBL go-PT1s
'I went home so that Ram wouldn't shout at me.'
b. Rām-le pro $_{i}$ na-kar-ā-os bhanera ma $\mathrm{mar}_{i}$ ghai ga-ẽ.
R.-ERG NEG-shout-3sIMP QUOTE 1sNOM home:OBL go-PT1s
'I went home so that Ram wouldn't shout at me.'

Another construction to which Nepali extends the Argument Sharing Constraint is based on aspectual and modal verbs. These 'light' verbs can appear in two constructions, one involving complex predicate formation (also known as 'clause union'), the other involving control in a biclausal structure. When a light verb forms a complex predicate together with an embedded verb, there is no control and the embedded verh determines the transitivity of the unified clause. This is why we get ergative marking in (39a), although lägnu 'to begin, take up' by itself is intransitive and licenses only nominative case on the S-argument (39b): ${ }^{10}$

(39) a. maile Hindī [v paḍh-na lāg-ẽ].

1sERG H.:NOM study-INF take.up-PT1s

'I took up studying Hindi.'
b. ma (*maile) yatã tira lāg-ẽ.
1sNOM 1sERG this.side towards take.up-PT1s
'I took this way.'

When there is no complex predicate formation, the embedded verb forms its own clause, which, however, shares its A- (40a) or S-argument $(40 \mathrm{~b})$ with the matrix:

\footnotetext{
10 Wallace (1985a: 127, 133) marks sentences like (39a) by an asterisk or in some cases by a question mark, but concedes that they do occur in discourse and he also gives one textual example. Our consultants accepted the examples without hesitating, but we cannot exclude dialect variation, which is wellknown to affect the distribution of -le 'ergative' in general.
} 
(40) a. $\mathrm{ma}_{i} \quad\left[\mathrm{IP} \emptyset_{i}\right.$ Hindī paḍh-na] lāg-ẽ.

$[\mathrm{N}]$

1sNOM H.:NOM study-INF take.up-PT1s

'I took up studying Hindi.'

b. $\mathrm{ma}_{i} \quad$ [IP $\emptyset_{i}$ hidu-na] lāg-ẽ.

1sNOM walk-INF take.up-PT1s

'I began to walk.'

Argument sharing in this construction is again subject to the constraint formulated in (28). Therefore, unlike nominative or ergative S/A-arguments, objects and dative $\mathrm{S} / \mathrm{A}$-arguments cannot be shared (41a). With objects, the intended meaning can be rendered through passivization, which promotes the object to a controllable S/Aposition (41b):

(41) a. ${ }^{*} \mathrm{ma}_{i} \quad$ [IP Harī-le $\phi_{i}$ piṭ-na] lāg-ẽ.

1sNOM H.-ERG beat-INF take.up-PT1s

b. $\mathrm{ma}_{i} \quad$ [IP $\emptyset_{i}$ Harī-bāta pit-ī-na] lāg-ẽ.

1sNOM H.-via beat-PASS-INF take.up-PT1s

'I began to be beaten by Hari.'

Dative S/A-arguments as in (42a) require complex predicate formation in order to be able to appear in a light verb construction $(42 \mathrm{~b}, \mathrm{c})$.

(42) a. malāī yo kitāb man par-yo.

1sDAT this book:NOM liking occur-PT3sM

'I liked this book.'

b. ${ }^{*} \mathrm{ma}_{i} \quad{ }_{\mathrm{IIP}} \emptyset_{i}$ yo kitāb man par-na] lāg-ẽ.

1sNOM this book:NOM liking occur-INF take.up-PT1s

'I began to like this book.'

c. malāî yo kitāb [v man par-na lāg-yo].

1sDAT this book:NOM liking occur-INF take.up-PT3sM

'I began to like this book.'

Notice that just like the ergative in (39a), the dative, too, is inherited in (42c) from the embedded verb man par- 'like' (which is itself complex) up to the main clause case-frame.

\subsection{Argument sharing in matrix-coding ('raising') constructions}

'Matrix-coding' has been proposed by Frajzyngier (1995) as a cover term for what has been variously called 'accusativus/nominativus cum infinitivo', 'raising' or 'exceptional case-marking', without assuming the particular case and movement theories implied by these other terms (also cf. Van Valin and LaPolla, 1997: 561-575). The construction involves arguments that are assigned case by the matrix but semantic role by the embedded clause. In Indo-Aryan, matrix-coding is wide-spread in the form of dative matrix-coding ('raising to object', 'exceptional case-marking') with 
verbs of perception. Apart from passive constructions, nominative matrix-coding ('raising to subject'), by contrast, is limited to two members of the so-called Bihāri group, Bhojpuri (Shukla, 1981) and Maithili (Yadava, 1998, 1999), where it involves evidential verbs similar to English to seem. We first discuss dative, then nominative matrix-coding.

In Nepali, matrix-coding does not involve argument sharing and even allows, given an appropriate information structure, doubling of the matrix-coded argument in the lower clause (see Frajzyngier, 1996: 261-288, for typological parallels).

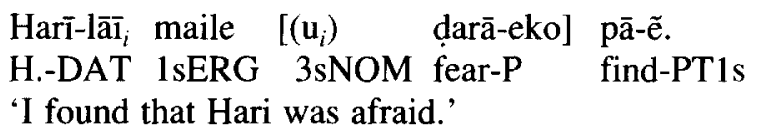

In line with this, there is no GR-constraint as to what can be matrix-coded, which encompasses even $\mathrm{O}$-arguments (44a) and dative $\mathrm{S}$-arguments (44b):

(44) a. Harī-lāīi ${ }_{i}$ [Rām-le pro ${ }_{i}$ pitịirah-eko] dekh-ẽ. H.-DAT R.-ERG beat-IPFV-P see-PT1s

'I saw Ram beating Hari.'

b. Harī-lāī ${ }_{i}$ maile $\left[\right.$ pro $_{i}$ dar lāg-eko] pã-ẽ. Hari-DAT 1sERG fear feel-P find-PT1s

'I found that he was afraid.'

This is radically different in Hindi and Maithili, where matrix-coding requires, as in English, argument sharing. That is, the matrix-coded argument must be covert and coindexed in the lower clause. Argument sharing in turn is subject to the same constraint as the one formulated in (28) for control constructions. ${ }^{11}$ This constraint can therefore be generalized over all constructions that involve argument sharing and, if we allow for vacuous application in some instances, over all languages under consideration:

(45) Constraint on argument sharing (generalized):

A shared argument must be in nominative or ergative S/A-role.

The following examples illustrate this for dative matrix-coding in Hindi and Maithili. The shared argument can be an experiencer A-argument only if this argument would be assigned nominative (or ergative) in a corresponding independent clause. Dative A-arguments are excluded (cf. Kachru et al., 1976): ${ }^{12}$

\footnotetext{
11 This finding receives a natural interpretation in Role and Reference Grammar, where control and matrix-coding constructions are both analyzed as building on the same clause linkage type, "coordinate core juncture'. See Van Valin and LaPolla (1997: 539-581) for discussion.

12 Singh (1983: 79) discusses Maithili data like Bäbuji hamrā hrișt boita dekhalathinh 'Father found me happy', claiming that the dative S-argument of hrist häyab 'to be happy', hamrä 'me', is 'raised' to
} 
(46) a. unko $_{i}$ maĩne $\left[\emptyset_{i}(* v a h)\right.$ dar-ā hu-ā $]$ pā-yā. 3sDAT 1sERG 3sNOM fear-PsM AUX-PsM find-PTsM
b. *
*unko ${ }_{i}$ maĩne
$\left[\emptyset_{i}\right.$ dar lag-ā
hu-ā]
$\mathrm{p} \bar{a}-y \bar{a}$.

3sDAT 1sERG fear feel-PsM AUX-PsM find-PT-1N

'I found that he was afraid.'
a. okră $_{i}$
ham $\left[\emptyset_{i}\left({ }^{*} \mathrm{u}\right)\right.$
daræ-1] pai-1-aũh.
3nhREM:DAT 1NOM 3nhREM:NOM fear-P find-PT-1N
b. ${ }^{*}$ okrā ham [ $\emptyset_{i}$ dar lāg-al] pai-l-aũh.
3nhREM:DAT 1NOM fear feel-P find-PT-1N
'I found that he $\mathrm{n}^{\text {nh.rem }}$ was afraid.'

Except for passive versions of the preceding examples, nominative matrix-coding is unknown in Nepali and Hindi, ${ }^{13}$ but well-attested in Maithili. Different from its better-known English counterpart, however, Maithili nominative matrix-coding involves finite subordinate clauses (see Lazard, 1998: 84, for typological parallels). Nevertheless, it is, like English, subject to argument sharing, i.e., the 'raised' element leaves a gap in the subordinate clause which cannot be filled by a resumptive pronoun or anything else (cf. Yadava, 1998, 1999):

(48) a. lag-ait ai-ch [je Harī-jī bimār bha-je-t-āh]. seem-IP 3nhN-AUX COMP H.-h:NOM sick be-TEL-FUT-3hN 'It seems that Hari will become sick.'

b. Harī-jīi lag-ait ch-aith [je $\emptyset_{i, * j}$ bimār bha-je-t-āh]. H.-h:NOM seem-IP AUX-3hN COMP sick be-TEL-FUT-3hN

c. ${ }^{*}$ Harī-ji $\bar{i}_{i}$ lag-ait ch-aith [je $o_{i, j}$ bimār H.-h:NOM seem-IP AUX-3hN COMP 3hREM:NOM sick bha-je-t-āh]. be-TEL-FUT-3hN

'Hari seems to become sick.'

This is in minimal opposition to an experiencer dative construction with lagab used in the sense of 'to feel'. In this case, no matrix-coding occurs, and pronouns are free to appear in the subordinate clause:

$$
\begin{aligned}
& \text { Hari-jī-kè } e_{i} \text { lag-ait ch-ainh [je } \quad\left(o_{i, j}\right) \text { bimār } \\
& \text { H.-h-DAT feel-IP AUX-3hNN COMP 3hREM:NOM sick }
\end{aligned}
$$

\footnotetext{
the matrix object position. We doubt whether hamrā is in fact raised here because unlike the matrix clausc constituents in (47a), it cannot be fronted: *Hamrā bābujī hrișt boita dekhalathinh sounds odd if not completely ungrammatical.

13 Unless one follows Davison (1985b) and Wallace (1985a) and analyzes constructions with Hi. lagnã and N. lagnu 'to take up, begin' as involving nominative matrix-coding ('raising-to-subject'). While, on semantic grounds, we prefer an analysis in terms of control (see section 4.2), the construction would still be subject to the same general Argument Sharing Constraint as set out in (45), even under a matrix-coding analysis. Also see note 11.
} 
bha-je-t-āh.]

be-TEL-FUT-3hN

'Hari feels that he $\mathrm{e}^{\mathrm{h} . \mathrm{rem}}$ will get sick.'

Argument sharing in Maithili nominative matrix-coding is subject to the general constraint formulated in (45): while, as is evident from (48b) above, patients in Sfunction can be shared, they cannot be shared in transitive O-function (50a). If promoted to $\mathrm{S}$ by means of passivization, however, sharing is again possible $(50 \mathrm{~b})$ :

a. ${ }^{*}$ Harī-ji $\bar{i}_{i}$ lag-ait ch-aith [je tũ $\emptyset_{i}$ nahi H.-h:NOM seem-IP AUX-3hN COMP 2mhNOM not dekh-l-ah-unh]. see-PT-2mhN-3hNN

'*Hari doesn't seem to you ${ }^{\text {mh }}$ have seen.'

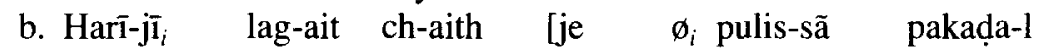
H.-h:NOM seem-IP AUX-3hN COMP police-ABL arrest-P ge-l-āh].

AUX:PASS-PT-3hN

'Hari seems to have been arrested by the police.'

Transitive A-arguments can be shared as well:

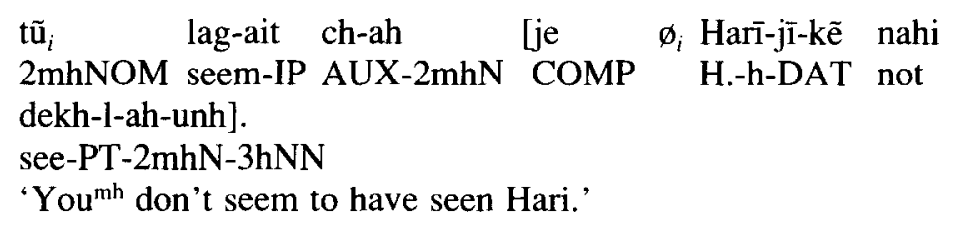

S-arguments in dative case are systematically excluded from the GR defined by (45). They cannot be shared - with or without their attached case-marking:

(52) a. lag-ait ai-ch [je Harī-jī-kẽ khuśî bhe-l-ainh]. seem-IP 3-AUX COMP H.-h-DAT happy be-PT-3hNN 'It seems that Hari was happy.'

b. ${ }^{*} \operatorname{Hari\overline {1}-j\overline {1}_{i}}$ lag-ait ch-aith [je $\emptyset_{i}$ khuś̂̄ bhe-l-ainh]. H.-h:NOM seem-IP AUX-3hN COMP happy be-PT-3hNN 'Hari seems to have been happy.'

c. *Hari-jī-kẽ $\tilde{i}_{i}$ lag-ait ch-ainh [je $\emptyset_{i}$ khuśî bhe-l-ainh]. H.-h-DAT seem-IP AUX-3hNN COMP happy be-PT-3hNN 'Hari seems to have been happy.'

This construction thus again confirms the generality of the Argument Sharing Constraint as proposed in (45): shared arguments, whether in control or matrix-coding constructions, must not be associated with any other case than nominative or ergative. 


\section{On some alleged subject properties of dative experiencer}

The literature on GRs in Indo-Aryan languages is full of claims that experiencer dative-arguments have syntactic subject properties (e.g., Davison, 1969, 1985a, 1985b; Klaiman, 1979; Gupta and Tuladhar, 1979/1980; Wallace, 1985a, 1985b; Abbi, 1990; Masica, 1991; Mohanan, 1994), although more cautious positions (Kachru et al., 1976; Bhatia, 1990; Hook, 1990; Verma, 1990) and dissenting voices (Mishra, 1990; Pandharipande, 1990) have gained some ground. If experiencer datives had indeed subject properties, GRs could be largely reduced to a notion of S/A-pivot, since experiencers are automatically assigned S- or A-status by the Thematic Hierarchy discussed in section 2 . Contradicting our claim, case would be irrelevant for the GR-definition. The constructions that are most commonly taken as evidence for the subjecthood of dative experiencers are converbial clause chaining, coordinate conjunction reduction, and reflexivization. In this section, we demonstrate that, under closer scrutiny, none of these constructions proves to be GR-sensitive to begin with. While there is certainly a strong universal pragmatic and semantic pressure to construe coreference around an S/A-pivot (cf. Verma, 1990; Dixon, 1994; Ichihashi-Nakayama, 1994, among others), it does not follow from this that a particular language grammaticalizes such a pivot as a syntactically defined, rigid GR. Without such a grammaticalization, however, the behavior of dative experiencers in these constructions does not tell us anything about GR-properties (but much about the pragmatic saliency of experiencers in discourse).

We saw in section 4.1 that converbs in Hindi and Maithili are sensitive to a GR defined by 'non-genitive S/A' (Hindi) or 'nominative S/A' (Maithili). Arguments bearing these GRs, and only these, are banned from appearing overtly in the converb clause, i.e., they are necessarily substituted by a $P R O$-element. It does not follow from this, however, that converbs are subject to a GR-sensitive constraint requiring coreference of the S- or A-argument. As examples (22) and (24b), repeated here as (53a) and (53b), show, converbial chains can contain overt S- and A-arguments with disjunct reference as long as they do not bear the proscribed GR:
a. tumhāre kal nahĩ ā-kar kuc kām nahĩ 2 mhGEN tomorrow not come-CONV some work:NOM not ho-gā. be:3s-FUTsM
'If you don't come tomorrow, there won't be any work.'
b. hamrā ghar āib-kẽ pitā-jī khuśī he-t-āh. IDAT home come-CONV father-h:NOM happy be(come)-FUT-3hN 'When I come home, father will be happy.'

Moreover, while there is a constraint on what can be a controlled $P R O$-element (viz., a non-genitive [Hindi] or a nominative [Maithili] S/A-argument), the question as to what can be its matrix clause controller is subject to pragmatic rather than syntactic constraints, in line with Tikkanen's (1995: 496) observation that "[...] in most South and Central Asian languages, the coreference restriction for same-subject con- 
verbs is semantic (constructio ad sensum), or even pragmatic (saliency-determined), rather than morphosyntactic". Thus, under appropriate pragmatic conditions, not only S/A-arguments, but also objects (54a), locations (54b) and possessors (54c) can control the reference of a converbial PRO (cf. Guru, 2026: \$627; Schumacher, 1977; Hook, 1990): ${ }^{14}$

(54) a. [PRO $O_{i}$ yahã̃ nahĩ $\left.\bar{a}-k a r\right]$, here not come-CONV maĩ tujhe ${ }_{i}$ kuc nahĩ sikhā sak-tā hũ. 1sNOM 2sDAT some not teach can-IP AUX:NPT1s 'If you don't come here, I can't teach you anything.'

b. $\left[P R O_{i}\right.$ ā-kar $]$ mere ${ }_{i}$ pās bet come-CONV 1sGEN:OBLsM near stick(sM):NOM gir-ga-yā. fall-TEL-PTsM

'A stick fell down near me when I came.' (Schumacher, 1977: 49)

c. $\left[P R O_{i}\right.$ uskī yah rukhāī dekh-kar $]$

3nhGENsF DEM rejection(sF):NOM see-CONV

Madhukar-ke $_{i}$ man-ko cot lag-ĩ. M.-GEN:OBLsM soul(sM)-DAT hurt(sF):NOM strike-PTsF

'Seeing this rejecting attitude of hers, Madhukar's feelings were hurt.' (Schumacher, 1977: 68)

The same appears to hold of imperfective converb clauses (Schumacher, 1977): $\begin{array}{llll}{\left[P R O_{i}\right.} & \text { khāt par par-e par-e } & \text { uske }_{i} & \text { cār-õ } \\ \text { bed on lie-ICONV lie-ICONV } & \text { 3nhGEN:OBLsM four-OBLp } \\ \text { or ek mohak, bhayānak-sā jāl jail-ga-yā. }\end{array}$ $[\mathrm{H}]$ side one magical frightening-like net(sM):NOM spread-TEL-PTsM 'When he was lying on the bed, a magical, somehow frightening net got spread around him.' (Schumacher, 1977: 204)

Indeed, converbs can also be without any explicit controller in the matrix at all (cf. Schumacher, 1977):

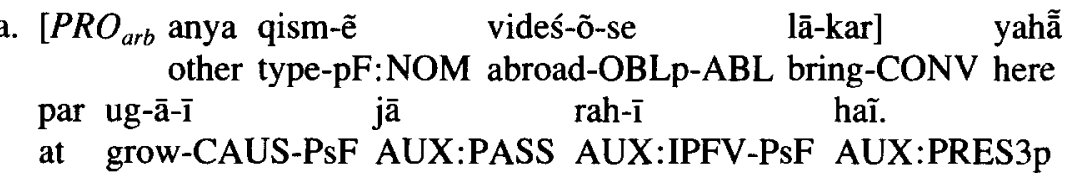
'[They] brought the other types [of peaches] from abroad and now they are grown here.' (Schumacher, 1977: 22)

14 If the converb shares the imperative force of the matrix as in Davison's (1985b: 165) example (jab sāri vyāvasthā ho jäe, to [PRO äkar] mujhe sucit kardenā 'When the whole arrangement is done, come and tell me'), only the A-argument is of course a possible controller. This is a purely pragmatic issue. 
b. $\left[P R O_{a r b}-k a r\right.$ lagā-kar pūrvakālik kriyā ban-tī hai.

CONV attach-CONV prior.tensed verb(sF):NOM make-IPsF

AUX:NPT3s

'The sequential verb is formed by attaching -kar.' (Schumacher, 1977: 24)

c. $\left[P R O_{a r b}\right.$ yah kām nahĩ ki-ye (hu-e)] kuc

DEM work(sM):NOM not do-ICONV AUX-ICONV some

nahĩ ban-e-gā.

not make-3s-FUTsM

'Nothing will happen without doing this work.'

The same findings apply to Maithili and many other Indo-Aryan languages.

Except for the presence of a $P R O$-element, conjunction reduction has similar properties as converbial chaining (and earlier literature often conflates the two, e.g., Kachru et al., 1976). In the pragmatically unmarked case, the dropped element (pro) is an S/A-argument, but this is not a syntactic constraint. The following examples show that under appropriate pragmatic and semantic conditions, the dropped element can also be the object:
a. $\operatorname{Ra}_{i} \quad \bar{a}-y \bar{a}$
aur sabõne $\mathrm{pro}_{i}$ pit-ne
lag-ā.
R.:NOM come-PTsM and all:ERG hit-INF:OBL begin-PTsM

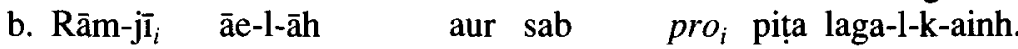

R-h:NOM come-PT-3hN and all:NOM hit begin-PT-3N-3hNN

c. $\operatorname{Ra}_{i}$ à-yo ra sabaile pro $_{i}$ pit-na lãg-e.

R.:NOM come-PT3sM and all:ERG hit-INF begin-PT3p

'Ram came and everybody started to hit him.'

In the same way, the coreferential antecedent of the zero anaphora (pro) can be object as much as subject: ${ }^{15}$

(58) a. maĩne glās $s_{i}$

$$
\text { phek-ā }
$$

aur pro $_{i}$ tut ga-yā.

$[\mathrm{H}]$

1sERG glass(sM):NOM throw-PTsM and break go-PTsM

b. ham glās ${ }_{i}$ phẽk-l-aũh aur pro $o_{i}$ tuit ge-l.

1NOM glass:NOM throw-PT-1N and break go-PT[3N]

$\begin{array}{llll}\text { c. maile gilas phyãk-e ra pro } & \text { phut-yo. } \\ \text { 1sERG glass:NOM throw-PT1s and } & \text { break-PT3sM }\end{array}$

'I threw the glass and it broke.'

Also within the clause, coreference relations do not observe a strict GR-constraint. Although they are frequently taken as evidence for the relevance of a notion

15 Mohanan (1994: 134) stars other sentences with a similar syntax (*Ravine äm ${ }_{i}$ kharidea aur $\phi_{i}$ khatțā nikla 'Ravi bought a mango and it turned sour'). It seems that argument dropping in coordination is possible only if the conjuncts are pragmatically tied together by a purpose relation. This needs further research, though. 
of 'subject', reflexives can in fact be controlled by both subjects and objects depending on lexical choice and pragmatic context. The following examples show reflexives controlled by object antecedents (cf., among others, Subbarao, 1971; Mahajan, 1990; Gurtu, 1992; Yadava, 1992):
a. Rām-ne patnī-ko apnīi $_{i}$ sārī d-î. R.-ERG wife-DAT REFLsF sari(sF):NOM give-PTsF
b. Rām patnī-kẽ $\operatorname{apan}_{i}$ sārī de-l-ak.
R.:NOM wife-DAT REFL sari:NOM give-PT-3N
c. Rām-le svasnī-lāīi ${ }_{i}$ âphno $_{i}$ sārī di-yo.
R.-ERG wife-DAT REFL sari:NOM give-PT3sM
'Ram gave his wife her own sari.'

However, whereas judgments in Maithili and Nepali were virtually uniform across consultants, there was some variation among native speakers of Hindi, and this is also what characterizes a recent debate in the literature (e.g., Gurtu, 1992; Mahajan, 1993; Dayal, 1994; Mohanan, 1994). While we concur with Comrie's (1998) proposal that such variation should be subject to careful and extensive sociolectal and dialectal research, the very fact of variation makes it unlikely that constraints on reflexive antecedents are a deep-reaching characteristic of Hindi, let alone Indo-Aryan syntax, on a par with the rigid constraints discussed in the preceding sections. Instead, it is more probable that the issue is a pragmatic one and we have to reckon, therefore, with the possibility that constraints on reflexives are vulnerable to deliberate normativization of grammaticality judgments through a quest for 'clarity' and 'avoidance of ambiguity'. Indeed, natural discourse examples of O-controlled reflexives are clearly attested - even in literary style, as is evidenced by the following example adduced by Hook (1990: 331):

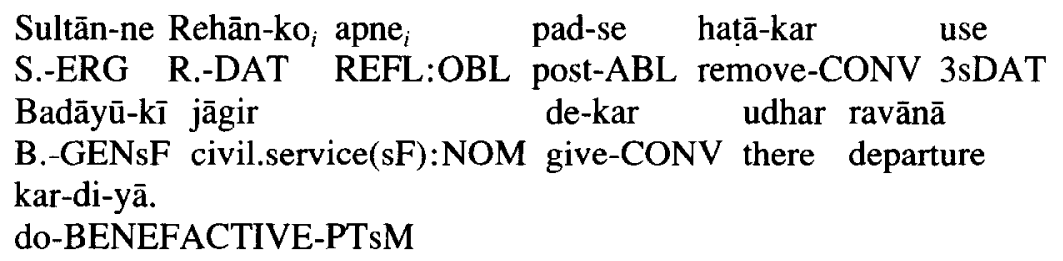

'The sultan removed Rehan from his (Rehan's) office and, giving him the Badayun jāgir, sent him there.'

Whatever the case may be, Hindi consultants were more uniform in their judgments of sentences with a distributive use of the reflexive. Again, the antecedent is in O-role, much as in the Maithili and Nepali examples:
(61) a. śikṣak-ne vidyārthi-yõ-ko ${ }_{i} \quad$ apnī apn $\overline{\mathbf{n}}_{i, *_{j}}$ kāpī teacher-ERG student-pOBL-DAT REFLsF notebook(sF):NOM lautā d-ī. return give-PTsF


b. śikṣak vidyārthī-sabh-kẽ $\tilde{i}_{i}$ apan apan ${ }_{i,{ }^{*} j}$ kāpī lautā [M] teacher:NOM student-p-DAT REFL notebook:NOM return de-l-aith. give-PT-3hN

c. śikșak-le vidyārthī-haru-lāī $\bar{i}_{i}$ aphna āphna ${ }_{i, *} k a \bar{p} \bar{i}$ teacher-ERG student-p-DAT REFL notebook:NOM pharkāi-di-yo. return-give-PT3sM

'The teacher returned the students their notebooks.'

Moreover, native speakers who reject O-bound reflexives, appear to accept them in experience clauses with a fronted stimulus, i.e., the O-argument (Mohanan and Mohanan, 1994: 175): ${ }^{16}$

(62) Nīnā $\bar{i}_{i} \quad$ Anū-ko $_{j}$ apnīi $_{i, j}$ bastī mẽ dikh-ī.

N.(F):NOM A.-DAT REFLsF neighborhood in see-PTsF

'Anu saw Nina in her own neighbordhood.'

If the antecedent condition relied simply on a pivot notion based on the Thematic Hierarchy, i.e., on 'subject' or ' $\mathrm{S} / \mathrm{A}$ ', the possibility of $\mathrm{O}$-binding in (62) would be unexplained. Apparently, reflexive binding is here sensitive, among other things, to a notion of linear precedence or phrase-structural configuration that is underdetermined by argument structure (see Mahajan, 1993 and Mohanan and Mohanan, 1994 for discussion of this in different theoretical frameworks) or, perhaps, to notions of sentential information structure (as developed in Van Valin and LaPolla, 1997). This suggests that even for those speakers who reject examples like (59) and (60), the constraints on reflexivization cannot be reduced to a hierarchy-driven pivot notion, but need to incorporate notions reflecting the structural position of NPs in the clause. Such properties of NPs, in turn, can be seen as functionally parallel to case, i.e., to the one NP-property that we argue to be crucial for Indo-Aryan GRs (see Bickel, 1999 , for further exploration of this).

Other Indo-Aryan languages seem to freely tolerate O-bound reflexives. Pandharipande (1990), for example, discusses the following examples from Marathi: ${ }^{17}$
a. $\mathbf{m i}_{i}$
tyāla $\bar{j}_{j}$
$\bar{a} p l y \bar{a}_{i, j}$ ghari
pāthav-to.
1sNOM 3sM:DAT REFL house:OBL send-NPTsM

[Marathi]

'I send him to my/his house.'

\footnotetext{
16 Note, however, that this construction is not possible in all dialects of Hindi.

17 Rosen and Wali (1989: 11f.) have examples contradicting this, but the verbs involved (di- 'give', sāngit- 'tell about someone', ne- 'take to someone's house'), are unlikely to accommodate object-bound reflexives on purely pragmatic reasons alone: unless one adds a notion of 'back' to 'give', object-binding is hard to get in A gave B REFL's book. Similarly, telling about oneself is common, but telling $B$ about $B$ is pragmatically highly marked. Finally, taking someone to his or her own house is more readily understood as involving one's own rather than someone else's home.
} 


\section{b. malā $\bar{a}_{i}$ to ${ }_{j}$ svatahā $\bar{*}_{i, j}$-cyā gharā-t dis-lā. \\ 1sDAT 3sM:NOM REFL-GENsOBL house-LOC see-PT3sM \\ 'I saw him in his (not: my) house.'}

Note that one of the two reflexives of this language, svatah, can only be bound by nominative arguments (63b), whatever their argument role.

Given these data, it does not come as a surprise that in some other Indo-Aryan languages reflexives can even appear in subject position (see Dixon, 1994: 138 and Lazard, 1998: 86 for typological parallels). This is notably the case in Nepali (64a), first explored in Yadava (1992). Mādhav Pokharel (in personal communication) suggested the example in (64b), which is even more striking:

$$
\begin{aligned}
& \text { a. āphai-le } \quad \text { Rām-lāĩ barbād gar-yo. } \\
& \text { self:EMPH-ERG R.-DAT spoiling do-PT3sM } \\
& \text { 'Ram got himself spoiled.' (lit. '*Himself spoiled Ram.') }
\end{aligned}
$$

b. āphu-le āphu-lāì cin-na sak-ena. REFL-ERG REFL-DAT know-INF be.able-3sNEG.PT 'One could not know oneself.'

Against this background, it is not surprising either that some dialects of Hindi marginally and some even completely, tolerate examples like the following, discussed by Mahajan (1990: 33):

$$
\begin{array}{lll}
\text { (') Mohan-ko }_{i} \text { apne }_{i} \text { baccõ-ne } & \text { mār-ā. } \\
\text { M.-DAT REL child:OBLpM-ERG } & \text { beat-PTsM } \\
\text { 'His own children beat Mohan.' } &
\end{array}
$$

Clearly, the grammar of Hindi reflexive binding is not based on a notion of 'subject' or ' $\mathrm{S} / \mathrm{A}$ ' that exclusively relies on the Thematic Hierarchy.

\section{Conclusions}

The Indo-Aryan languages we looked at in this article are all sensitive to GRs that are defined by both case features and argument roles. Table 2 summarizes the findings (where we assume that the notion 'ergative' applies vacuously in Maithili). Interestingly, in spite of their differences in case and agreement typology, all three languages manifest the same basic GR defined as 'nominative or ergative S/A'. Hindi shows a split between a majority of constructions involving the same GR as the other languages and two constructions - verb agreement and converbial gapping - involving GRs that are defined in a slightly different way. However, even in this case, the GRs are sensitive to both case and argument roles. In none of the languages we looked at did we find robust patterns of a GR that would be definable as 'S/A pivot' or 'subject' without any sensitivity to case-features. Candidates for such patterns that have been suggested in the literature (conjunction reduction, converb con- 
trol, and reflexives), turned out to be contradicted by further data. In one case, viz. reflexives, we found variation among Hindi speakers suggesting that there may be a partial sensitivity to a case-neutral pivot notion. However, closer investigation showed that even in those varieties which seem to incorporate such a notion, reflexivization would still be sensitive to some property of an NP in its phrase-structural or information-structural environment, and this can be seen as being functionally similar to a morphological NP-property, viz. case (see Bickel, 1999). Moreover, the very fact of data variation suggests that the relevant constraints would be a fairly shallow property of one single construction - certainly not a fundamental over-all characteristic of the language. This is in stark contrast with the case-sensitive GRs, for which we found no trace of data variation whatsoever, and which indeed show their syntactic relevance even where the pragmatics of the sentence would accommodate or even invite violation of GR-restrictions. Maithili speakers invariably reject matrix-coding constructions like *Harijī lagait chaith je khuśi bhelainh 'Hari seems to have been happy', even though the proposition makes much sense both pragmatically and semantically. Indeed, the version without matrix-coding is, as we saw in section 4.3 , perfectly grammatical.

Table 2

Overview of GRs in three Indo-Aryan languages

\begin{tabular}{llll}
\hline & Hindi & Maithili & Nepali \\
\hline Nominative or ergative S/A & + & + & + \\
Highest nominative & + (verb agreement) & - & - \\
Non-genitive S/A & + (in converbs) & - & - \\
\hline
\end{tabular}

Thus, the languages we looked at in this paper, and possible Indo-Aryan languages in general, do show strong and clear evidence for GRs. However, the GRs we found are defined in a different way from what we are used to expect in most current theoretical frameworks. Case is a crucial ingredient of GR-definitions in these languages. Therefore, the linking from semantics to syntax cannot be universally reduced, as is often done, to information contained in the lexical predicate. Linking is instead sensitive to clause-level information contained in case frames (cf. Croft, 1993, 1998; Goldberg, 1995; Levin and Rappaport-Hovav, 1996; Bickel, 1999).

\section{References}

Abbi, A., 1990. Experiental constructions and the 'subjecthood' of the experiencer NPs in South Asian languages. In: M.K. Verma and K.P. Mohanan (eds.), Experiencer subjects in South Asian languages, 253-267. Stanford, CA: CSLI.

Anderson, S.R., 1976. On the notion of subject in ergative languages. In: C.N. Li (ed.), Subject and topic, 1-23. New York: Academic Press.

Bashir, E., 1990. Involuntary experience in Kalasha. In: M.K. Verma and K.P. Mohanan (eds.), Experiencer subjects in South Asian languages, 297-318. Stanford, CA: CSLI. 
Bhatia, T.K., 1990. The notion of 'subject' in Punjabi and Lahanda. In: M.K. Verma and K.P. Mohanan (eds.), Experiencer subjects in South Asian languages, 181-194. Stanford, CA: CSLI.

Bickel, B., 1997. Double-marking languages and morphosyntactic typology. Paper presented at the Second Conference of the Association for Linguistic Typology, Eugene, Oregon, 11-14 September 1997.

Bickel, B., 1999. Grammatical relations, agreement, and genetic stability. Manuscript, University of California at Berkeley [http://socrates.berkeley.edu/ bickel/papers].

Bickel, B., in press. Hidden syntax in Belhare. In: G. van Driem (ed.), Himalayan linguistics. Berlin: Mouton de Gruyter.

Bickel, B., W. Bisang and Y.P. Yãdava, 1999. Face vs. empathy: The social foundation of Maithili verb agreement. Linguistics 37, 481-518.

Bossong, G., 1985. Empirische Universalienforschung: Differentielle Objektmarkierung in neuiranischen Sprachen. Tübingen: Narr.

Bresnan, J. and J. Kanerva, 1989. Locative inversion in Chichewa: A case study in factorization in grammar. Linguistic Inquiry 20, 1-50.

Clark, T.W., 1989. Introduction to Nepali. Kathmandu: Ratna Pustak Bhandar.

Comrie, B., 1998. South Asian languages and linguistic typology. The Yearbook of South Asian Languages and Linguistics 1998, 237-246.

Croft, W., 1993. Case marking and the semantics of mental state verbs. In: J. Pustejovsky (ed.), Semantics and the lexicon, 55-72. Dordrecht: Kluwer.

Croft, W. 1998. Event structure in argument linking. In: M. Butt and W. Geuder (eds.), The projection of arguments, 21-63. Stanford, CA: CSLI.

Davison, A., 1969. Reflexivization and movement in relation to a class of Hindi psychological predicates. Papers from the Fifth Regional Meeting of the Chicago Linguistic Society, 37-51.

Davison, A., 1985a. Case and control in Hindi-Urdu. Studies in the Linguistic Sciences 15, 9-23.

Davison, A., 1985b. Experiencers and patients as subjects in Hindi-Urdu. In: A.R.K. Zide, D. Magier and E. Schiller (eds.), Proceedings of the conference on participant roles: South Asia and adjacent areas, 160-178. Bloomington, IN: Indiana University Linguistics Club.

Davison, A., 1988. Constituent structure and the realization of agreement features. Papers from the 24th Annual Regional Meeting of the Chicago Linguistics Society, 41-53.

Dayal, V.S., 1994. Binding facts in Hindi and the scrambling phenomenon. In: M. Butt, T.H. King and G. Ramchand (eds.), Theoretical perspectives on word order in South Asian languages, 237-261. Stanford, CA: CSLI.

Dixon, R.M.W., 1979. Ergativity. Language 55, 59-138.

Dixon, R.M.W., 1994. Ergativity. Cambridge: Cambridge University Press.

Foley, W.A. and R.D. Van Valin, Jr., 1984. Functional syntax and universal grammar. Cambridge: Cambridge University Press.

Frajzyngier, Z., 1995. Functional theory of matrix coding. Paper presented at the Conference on Functional Approaches to Grammar, Albuquerque, New Mexico, 24-28 July 1995.

Frajzyngier, Z., 1996. Grammaticalization of the complex sentence: A case study in Chadic. Amsterdam: Benjamins.

Gair, J.W., 1971. Action involvement in Colloquial Sinhalese. In: M.D. Zamora, J.M. Mahar and H. Orenstein (eds.), Themes in culture: Essays in honor of Morris E. Opler, 238-256. Manila: Kayumanggi Publishers [reprinted in: J.W. Gair, Studies in South Asian linguistics, 25-43. New York: Oxford University Press].

Gair, J.W. and K. Wali, 1989. Hindi agreement as anaphor. Linguistics 27, 45-70.

Givón, T., 1984. Syntax: A functional-typological introduction, vol. 1. Amsterdam: Benjamins.

Goldberg, A., 1995. Constructions: A Construction Grammar approach to argument structurc. Chicago, IL: The University of Chicago Press.

Gupta, S.M. and J. Tuladhar, 1979/1980. Dative subject constructions in Hindi, Nepali and Marathi and Relational Grammar. Contributions to Nepalese Studies 7, 119-153.

Gurtu, M., 1992. Anaphoric relations in Hindi and English. Delhi: Munshiram Manoharlal.

Guru, K., 2026 (VS). Hindī vyākaraṇ. Kās̄ĩ: Nāgarī Pracātiṇi Sabhā. 
Hook, P.E., 1979. Hindi structures: Intermediate level. Ann Arbor, MI: Center for South and Southeast Asian Studies, University of Michigan.

Hook, P.E., 1990. Experiencers in South Asian languages: A gallery. In: M.K. Verma and K.P. Mohanan (eds.), Experiencer subjects in South Asian languages, 319-334. Stanford, CA: CSLI.

Ichihashi-Nakayama, K., 1994. On dative 'subject' constructions in Nepali. In: C. Genetti (ed.), Santa Barbara Papers in Linguistics, Aspects of Nepali grammar, 41-76. Santa Barbara, CA: Department of Linguistics, University of California.

Kachru, Y., B.B. Kachru and T.K. Bhatia, 1976. The notion 'subject': A note on Hindi-Urdu, Kashmiri, and Panjabi. In: M.K. Verma (ed.), The notion of subject in South-Asian languages, 79-109. Madison, WI: South Asian Studies Publications Series, University of Wisconsin.

Klaiman, M.H., 1979. On the status of the subjecthood hierarchy in Hindi. International Journal of Dravidian Linguistics 8, 17-31.

Lazard, G., 1994. L'actance. Paris: Presses Universitaires de France.

Lazard, G., 1998. Définition des actants dans les langues européennes. In: J. Feuillet (ed.), Actance et valence dans les langues de l'Europe, 11-146. Berlin: Mouton.

Levin, B. and M. Rappaport-Hovav. 1996. From lexical semantics to argument realization. Manuscript, Northwestern University [http://www.ling.nwu.edu/ beth/pubs.html].

Mahajan, A., 1990. The A/A' distinction and movement theory. Ph.D. dissertation, MIT.

Mahajan, A., 1993. Toward a unified theory of scrambling. In: N. Corver and H. van Riemsdijk (eds.), Studies in scrambling, 301-330. Berlin: Mouton de Gruyter.

Masica, C.P., 1991. The Indo-Aryan languages. Cambridge: Cambridge University Press.

Mishra, M., 1990. Dative/experiencer subjects in Maithili. In: M.K. Verma and K.P. Mohanan (eds.), Experiencer subjects in South Asian languages, 105-117. Stanford, CA: CSLI.

Mohanan, K.P. and T. Mohanan, 1994. Issues in word order in South Asian languages: Enriched phrase structure or multidimensionality? In: M. Butt, T.H. King and G. Ramchand (eds.), Theoretical perspectives on word order in South Asian languages, 153-184. Stanford, CA: CSLI.

Mohanan, T., 1994. Argument structure in Hindi. Stanford, CA: CSLI.

Palmer, F.R., 1994. Grammatical roles and relations. Cambridge: Cambridge University Press.

Pandharipande, R., 1990. Experiencer (dative) NPs in Marathi. In: M.K. Verma and K.P. Mohanan (eds.), Experiencer subjects in South Asian languages, 161-179. Stanford, CA: CSLI.

Rosen, C. and K. Wali, 1989. Twin passives, inversion and multistratalism in Marathi. Natural Language and Linguistic Theory 7, 51-92.

Schumacher, R., 1977. Untersuchungen zum Absolutiv im modernen Hindi. Frankfurt a.M.: Lang.

Shukla, S., 1981. Bhojpuri grammar. Washington, DC: Georgetown University Press.

Singh, U.N., 1983. Subjecthood hierarchy in Maithili. Indian Linguistics 44, 75-81.

Subbarao, K.V., 1971. Notes on reflexivization in Hindi. Studies in the Linguistic Sciences 1, 180-214.

Subbarao, K.V., 1984. Complementation in Hindi syntax. Delhi: Academic Publications.

Tikkanen, B., 1995. Burushaski converbs in their South and Central Asian areal context. In: M. Haspelmath and E. König (eds.), Converbs in cross-linguistic perspective, 487-528. Berlin: Mouton.

Van Valin, R.D., Jr., and R.J. LaPolla, 1997. Syntax: Structure, meaning, and function. Cambridge: Cambridge University Press.

Verma, M.K., 1976. The notion of subject and the data from Nepali. In: M.K. Verma (ed.), The notion of subject in South-Asian languages, 270-286. Madison, WI: South Asian Studies Publications, University of Wisconsin.

Verma, M.K., 1990. Experiencer subjects in Bhojpuri and Magahi. In: M.K. Verma and K.P. Mohanan (eds.), Experiencer subjects in South Asian languages, 85-103. Stanford, CA: CSLI.

Wallace, W.D., 1985a. Constituent roles and clause union in Nepali. In: A.R.K. Zide, D. Magier and E. Schiller (eds.), Proceedings of the conference on participant roles: South Asia and adjacent areas, 119-148. Bloomington, IN: Indiana University Linguistics Club.

Wallace, W.D., 1985b. Subjects and subjecthood in Nepali: An analysis of Nepali clause structure and its challenges to Relational Grammar and Government and Binding. Ph.D. dissertation, University of Illinois, Urbana-Champaign.

Yadava, Y.P., 1992. Anaphoric relations in Maithili, Nepali and English: A cross-linguistic study. Nepalese Linguistics 9, 11-23. 
Yadava, Y.P., 1996. Verb agreement in Maithili. Journal of Nepalese Studies 1, 109-121.

Yadava, Y.P., 1997. Verb agreement in Maithili, Hindi and Nepali. Paper presented at the Third Himalayan Languages Symposium, Santa Barbara, California, 18-20 July.

Yadava, Y.P., 1998. Issues in Maithili syntax. München: Lincom Europa.

Yadava, Y.P., 1999. Raising from a tensed clause and linguistic theory. In: Y.P. Yadava, W.W. Glover (eds.), Topics in Nepalese linguistics, 250-270. Kathmandu: Royal Nepal Academy. 